\title{
Inequities in the freedom to lead a flourishing and healthy life: issues for healthy public policy
}

\author{
Sharon Friel ${ }^{\star}$
}

Abstract

There are many reasons for the health inequities that we see around the world today. Public policy and the way society organises its affairs affects the economic, social and physical factors that influence the conditions in which people are born, grow, live, work and age - the social determinants of health. Tackling health inequities is a political issue that requires leadership, political courage, progressive public policy, social struggle and action, and a sound evidence base.

Keywords: Health Inequalities, Social Determinants, Public Policy

Copyright: @ 2014 by Kerman University of Medical Sciences

Citation: Friel S. Inequities in the freedom to lead a flourishing and healthy life: issues for healthy public policy. Int J Health Policy Manag 2014; 3: 161-163. doi: 10.15171/ijhpm.2014.82
Article History:

Received: 15 August 2014

Accepted: 1 September 2014

ePublished: 2 September 2014

\section{${ }^{*}$ Correspondence to:}

Sharon Friel

Email: Sharon.friel@anu.edu.au
$\mathrm{T}$ The freedom to live a long, flourishing, and healthy life is unequally distributed between and within countries. Males born in Cambodia can expect to live 23 years less than males born in Japan. There is no biological reason for such a difference in life expectancy between countries (1). Within-country inequities also exist the world over. In a prosperous country such as Australia the poorest 20\% of the population can still expect to die younger (six years on average) compared to the richest $20 \%$ of the population (2). The incidence and prevalence of communicable diseases are highly socially graded and people who are more socially disadvantaged by income, employment status, education, ethnicity have a higher risk of non-communicable diseases including depression, diabetes, heart disease and cancers $(1,3-7)$.

It does not have to be like this. Systematic social differences in health outcomes are not explained by genetic variation or because of some mythical deviant behaviour that is particular to socially disadvantaged groups. Most societies are stratified along a range of intersecting social categoriesincome, education, occupation, gender, age, ethnicity and geography-in which economic and social resources are distributed unequally. Pursuit of health equity recognises the need to redress the inequitable distribution of these resources. Creating a fairer distribution of the resources relates to freedoms and empowerment, at the individual, community, and whole country level. Empowerment is affected by three core things: basic material requisites for a decent life, control over our lives, and voice and participation in the policy decisions that affect the conditions in which people are born, grow, live, work, age and die, e.g. the type of exposure and access to quality and affordable education and healthcare, affordable nutritious food, good conditions of work and leisure, and quality of housing and built environment. These dimensions of empowerment are influenced by public policy and the way in which society, at the international, national and local level, chooses to run its affairs $(8,9)$.

While health policy, in particular healthcare policy, can go some of the way to reduce health inequities, health inequities are every government department and sector's problem. If done well, education, urban planning, rural development, working conditions, social protection and legal systems, to take just a few examples, can improve health equity.

The following story illustrates how health policy and other public policy areas affect health inequities. The point of the story is to highlight not only the complexity of issues that affect people's health but also the many policy levers, and therefore opportunities, that can be used to improve health and health equity.

Anna is 44 years old and lives at home with her elderly mother in one of the most socio-economically disadvantaged urban areas in the country. She is quite overweight, smokes a lot and suffers from depression but is not inclined to visit her doctor. Healthcare systems can be powerful mechanisms to reduce inequities (10), but the inverse care law, in which the poor consistently gain less from health services than the better off, is visible in every country across the globe (11). Out-ofpocket expenditures for healthcare can deter poorer people from using both essential and non-essential services, leading to untreated morbidity $(12,13)$. But inequities in access and utilisation of healthcare are not only financial - inequities play out by race, gender, age and location. For example, in spite of near universal coverage for antenatal visits in Pelota, Brazil, the quality of care was consistently higher among women of white skin colour and high socio-economic status women than among black and poor women (14).

Although Anna completed high school, it was a very mixed experience for her-teachers were regularly absent, the toilet areas were renowned for the bullying that went on there, and there was little expectation of lower social status children 
to do well academically-Anna left school with very few qualifications. It is known that children from economically disadvantaged backgrounds are more likely to do poorly in school and drop out early - and subsequently as adults are more likely to have lower incomes and are less empowered to provide for themselves and family (15). Quality education is critical for the well-being of individuals and communities. It helps to equip people with the resources needed throughout life to achieve a secure income, provide for family, and cope with health outcomes in later life. Beyond better outcomes for the individual, education and skills are vital for resilient communities by strengthening inclusiveness, tolerance, trust, ethics, responsibility, collaboration and effective democratic processes (16).

Labour policy also affects health and health inequities. Ensuring working conditions that provide sufficient income to comply with health needs, and job security such that workers have a greater sense of control over their lives are fundamental requirements of a cohesive and healthy society (17). In developing countries, a high proportion of people are employed in the informal sector. In high-income countries there has been growth in job insecurity and precarious employment arrangements (such as temporary work, parttime work, informal work, and piece work) and job losses (18). These changes in the labour market have affected working conditions, with increasingly less job control, financial and other types of security, work hour flexibility, and access to paid family leave (19). Anna works in a call centre for a large telecommunications company. Her job involves dealing with customer complaints all day, every day. She has no control over the nature of her work or how it gets done, other than to use the mute button on the call. The evidence shows us that the quality of working conditions is related to mental health - poor quality work can in fact be worse for health than not having a job at all (20).

On the up side, she has a permanent position with 6 weeks holiday per year. However her wage has not increased in the past 5 years - the company tells the workers that it cannot afford to increase wages because of the global financial crisis. Thankfully the social protection, including health insurance provided by her company has not been cut, unlike much of what is happening internationally across the public sector where strong austerity measures have been implemented, cutting health and social services with subsequent impacts on communicable disease risk and suicides (21).

Anna is financially reliant on her single wage, which is only slightly higher than the minimum wage. She cannot afford to buy her own place hence one of the reasons why she lives at home with her mother. People with precarious and low paid employment do not have the easy choice of living in areas close to their work. House prices are partly to blame for this social disconnection. The land value gradient growth in recent years in many cities internationally is reinforcing a very strong social stratification of choice and opportunity for generations to come (22). To get to work by public transport Anna has to walk 20 minutes to the bus stop and take 2 buses-there are no trains-which would take about 90 minutes. She drives. We know that built environments that are walkable, with easy access to services and green space is very important for physical and mental health $(23,24)$. So even if Anna wanted to walk in a pleasant environment, her opportunities to do so are more likely to be curtailed because of where she lives.

An overarching issue for Anna's well-being is the systematically unequal distribution of power that is often experienced among socially disadvantaged groups, manifesting, as illustrated here, in inequities in material resources and psychosocial control. Health equity requires inclusion and agency (25), requiring individuals and groups to represent their needs and interests strongly and effectively. For example, at a local level, Blacksher and Lovasi demonstrate how engagement of people in the development of policy and practice relating to the design of the built environment creates better outcomes for socially disadvantaged communities (26). Work by Bartels has brought attention to the vast disconnect between poorer voters and the political system (27). Other international research shows that with greater income inequality people are less satisfied with the way democracy works and the residents of these countries are less trusting of their politicians and parliaments (28).

Having the freedom to lead a healthy and flourishing live is not experienced equally as this story of Anna illustrates. Whilst there are signs of hope, significant challenges remain for health equity globally. The health gains that have been made to date are not inevitable, nor equally distributed, nor is continued progress guaranteed as the world encounters new economic, social and environmental challenges. Tackling health inequities is a political issue that requires leadership, political courage, progressive public policy, social struggle and action, and a sound evidence base (1).

\section{Ethical issues \\ Not applicable.}

Competing interests

The author declares that she has no competing interests.

Author's contribution

$\mathrm{SF}$ is the single author of the manuscript.

\section{References}

1. AP-HealthGAEN. An Asia Pacific spotlight on health inequity: Taking Action to Address the Social and Environmental Determinants of Health Inequity in Asia Pacific, 2011. Canberra: Global Action for Health Equity Network (HealthGAEN); 2011.

2. Leigh A. Battlers \& Billionaires: the Story of Inequality in Australia. Collingwood: Redback; 2013.

3. Murray CJL, Kulkarni SC, Michaud C, Tomijima N, Bulzacchelli MT, landiorio TJ, et al. Eight Americas: Investigating Mortality Disparities across Races, Counties, and Race-Counties in the United States. PLoS Med 2006; 3: e260. doi: 10.1371/journal. pmed.0030260

4. Yach D, Leeder SR, Bell J, Kistnasamy B. Global Chronic Diseases. Science 2005; 307: 317. doi: 10.1126/ science. 307.5708 .317

5. Schmidhuber J, Shetty P. The nutrition transition to 2030. Why developing countries are likely to bear the major burden. Acta Agriculturae Scandinavica, Section C-Economy 2005; 2: 150 66. doi: 10.1080/16507540500534812

6. Marmot MG, Smith GD, Stansfeld S, Patel C, North F, Head J, et 
al. Health inequalities among British civil servants: the Whitehall II study. Lancet 1991; 337: 1387-93. doi: 10.1016/01406736(91)93068-k

7. Gupta R. Smoking, educational status and health inequity in India. Indian J Med Res 2006; 124: 15-22.

8. Commission on Social Determinants of Health (CSDH). Closing the gap in a generation: health equity through action on the social determinants of health. Final report of the Commission on Social Determinants of Health. Geneva: WHO; 2008.

9. Marmot M, Friel S, Bell R, Houweling TAJ, Taylor S. Closing the gap in a generation: health equity through action on the social determinants of health. Lancet 2008; 372: 1661-9. doi: 10.1016/ s0140-6736(08)61690-6

10. World Health Organisation (WHO). The World Health Report 2010 - Health systems financing: the path to universal coverage. Geneva: WHO; 2010.

11. Tudor-Hart J. The inverse care law. Lancet 1971; 1: 405-12. doi: 10.1016/s0140-6736(71)92410-x

12. Kemp A, Preen D, Glover J, Semmens J, Roughead E. Impact of cost of medicines for chronic conditions on low income households in Australia. J Health Serv Res Policy 2013; 18: 21-7. doi: 10.1258/jhsrp.2012.011184

13. McIntyre D, Garshong B, Mtei G, Meheus F, Thiede M, Akazili $\mathrm{J}$, et al. Beyond fragmentation and towards universal coverage: insights from Ghana, South Africa and the United Republic of Tanzania. Bull World Health Organ 2008; 86: 871-6. doi: 10.2471/blt.08.053413

14. Victora C, Matijasevich A, Silveira M, Santos I, Barros A, Barros F. Socio-economic and ethnic group inequities in antenatal care quality in the public and private sector in Brazil. Health Policy Plan 2010; 25: 253-61. doi: 10.1093/heapol/czp065

15. Grantham-McGregor S, Cheung YB, Cueto S, Glewwe P, Richter L, Strupp B. Developmental potential in the first 5 years for children in developing countries. Lancet 2007; 369: 60-70. doi: 10.1016/s0140-6736(07)60032-4

16. The Organisation for Economic Co-operation and Development (OECD). PISA 2012 Results: Excellence Through Equity: Giving Every Student the Chance to Succeed (Volume II). Paris: OECD Publishing; 2013.

17. Joan B, Carles M, Haejoo C, Orielle S, Vilma S, Sharon F, et al.
The importance of government policies in reducing employment related health inequalities. BMJ 2010; 340 . doi: 10.1136/bmj. c2154

18. Australian Council of Trade Unions (ACTU). The report of the Independent Inquiry into Insecure Work in Australia. Canberra: ACTU; 2012.

19. Benach J, Muntaner C. Precarious employment and health: developing a research agenda. $J$ Epidemiol Community Health 2007; 61: 276-7. doi: 10.1136/jech.2005.045237

20. Broom D, D'Souza RM, Strazdins L, Butterworth P, Parslow $\mathrm{R}$, Rodgers $\mathrm{B}$. The lesser evil: Bad jobs or unemployment? A survey of mid-aged Australians. Soc Sci Med 2006; 63: 575-86.

21. Stuckler D, Basu S. The Body Economic: Why Austerity Kills. London: Penguin; 2013.

22. Major Cities Unit. State of Australian Cities 2013. Canberra: Department of Infrastructure and Transport; 2013.

23. Giles-Corti B, Bull F, Knuiman M, McCormack G, Van Niel K, Timperio A, et al. The influence of urban design on neighbourhood walking following residential relocation: Longitudinal results from the RESIDE study. Soc Sci Med 2013; 77: 20-30. doi: 10.1016/j. socscimed.2012.10.016

24. Smit W, Hancock T, Kumaresen J, Santos-Burgoa C, SánchezKobashi Meneses R, Friel S. Toward a Research and Action Agenda on Urban Planning/Design and Health Equity in Cities in Low and Middle-Income Countries. J Urban Health 2011; 88: 875-85. doi: 10.1007/s11524-011-9605-2

25. Social Exclusion Knowledge Network (SEKN). Understanding and tackling social exclusion. Final Report of the Social Exclusion Knowledge Network of the Commission on Social Determinants of Health. Geneva: World Health Organization (WHO); 2007.

26. Blacksher E, Lovasi G. Place-focused physical activity research, human agency, and social justice in public health: Taking agency seriously in studies of the built environment. Health Place 2012; 18: 172-9. doi: 10.1016/j.healthplace.2011.08.019

27. Bartels L. Unequal democracy: The political economy of the new gilded age. Princeton, NJ: Princeton University Press; 2009.

28. Schafer A. Consequences of social inequality for democracy in Western Europe. Zeitschrift für Vergleichende Politikwissenschaft 2012; 6: 23-45. doi: 10.1007/s12286-010-0086-6 